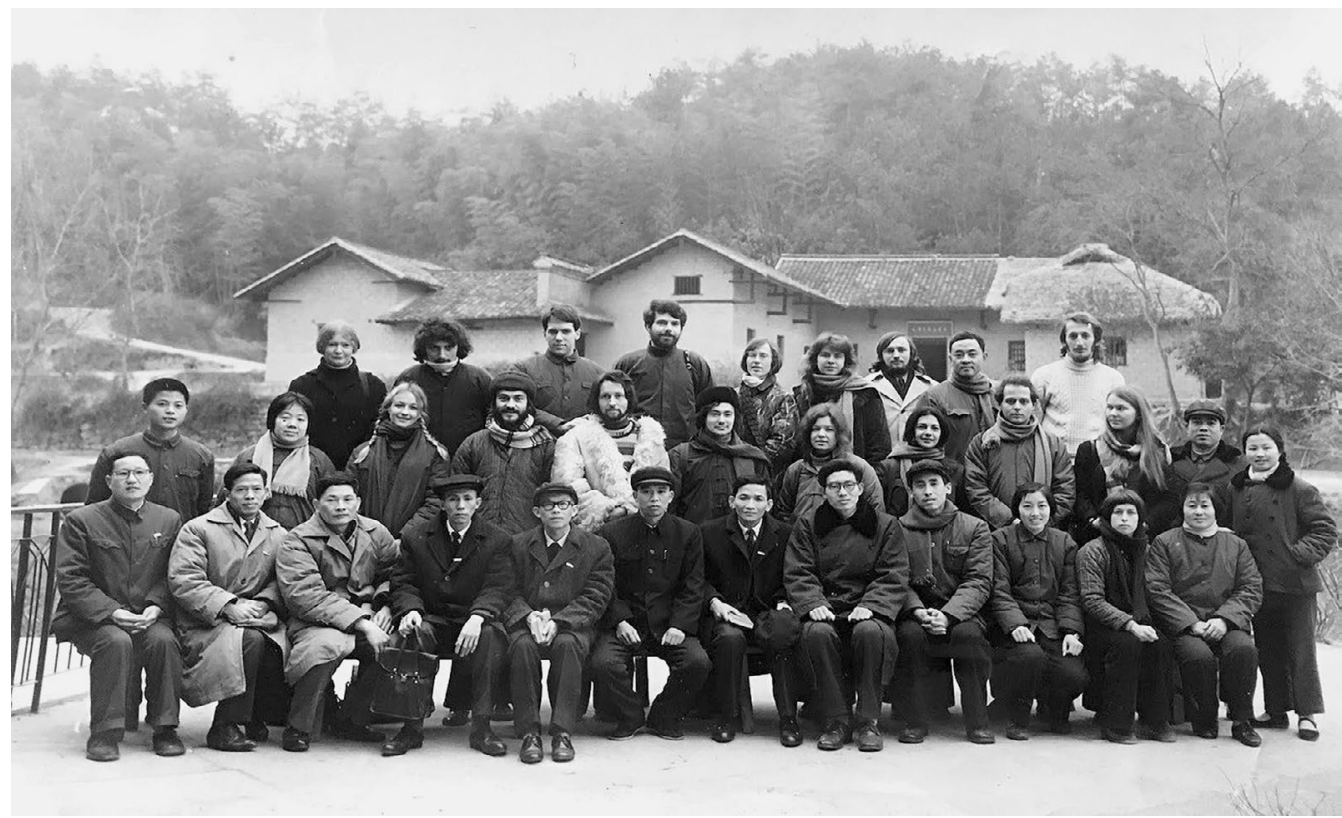

Geremie R. Barmé (back row, third from left) visiting Mao Zedong's former residence at Shaoshanchong during the 1975 Spring Festival. Image courtesy of Geremie R. Barmé.

白杰明（后排左三）于1975年春节期间参观韶山冲毛泽东故居。白杰明惠允。 


\title{
Something in the air
}

\author{
Geremie R. Barmé
}

\section{Enemy news}

Tōutīng dítái!

偷听敌台!

The gruff voice barked over the concrete trough. I was in the washroom of our dorm building at the Beijing Foreign Languages Institute, having arrived from Australia only a few days earlier. He was a worker-peasant-soldier study officer 工农兵学员 (Maoist Chinese for 'student') wearing, even at that darkling hour in the morning, a high-collared blue Mao jacket. Steely-faced, his tone was one of warning and accusation. I had no idea what he'd just said.

'You're secretly listening to enemy broadcasts!'

It was October 1974, and I was a naive and eager exchange student who had just finished two and a half years of Chinese in Canberra. In the cold and forbidding dormitory washroom, I had placed my small radio-listening to which I hoped would improve my Chinese comprehension-on the dividing ledge of the wash trough. l'd tuned in to a radio station with a broadcaster who wasn't just reading in a harsh staccato, and at seemingly impossible speed, the same news blaring out of the loudspeakers around the campus. The voice was in near dulcet tones, quite different from the shrill delivery of Central People's Radio. I presumed that this milder voice must be coming from some local station, or even a provincial broadcaster speaking in the clear and calm Chinese I had become used to from classes at The Australian National University. 


\section{Sūxiū guăngbō!}

苏修广播!

My interlocutor spat: 'It's a Soviet Revisionist broadcast!'

Our teachers had introduced us to basic Maoist Chinese. In our third year of undergraduate studies we'd read some Red Flag articles in class and more general guff from the People's Daily, and I had leafed through Peking Review, so I knew the basics: American imperialism 美帝, Soviet revisionism 苏修, counter-revolution 反革命 and Chiang Kai-shek bandits 蒋匪, as well as Chairman Mao's three oppressive mountains 三座大山 of feudalism, capitalism and semicolonialism 封建主义, 资本主义, 半殖民主义. Although as a foreigner l'd been listening to 'enemy broadcasts' my whole life, I didn't know the expression ditái 敌台. Now l'd never forget it.

It was in high school in Sydney that l'd first been exposed to People's Radio. One of my friends at Randwick Boys High was Samson Voron, a ham (amateur) radio enthusiast. We were both a priori Trekkies; Samson even had the look of a youthful Spock, his Russian ancestry giving him the smooth features and eyes (but not the pointy ears) of the laconic science officer of the Starship Enterprise. Sam couldn't make it into space or teleport to other worlds, but long hours spent searching the airwaves at night brought him as close as possible to being a terrestrial global citizen.

Even in those jejune years Samson knew that I was interested in Taoism, Tibetan Buddhism and Indian mysticism; he thought l'd probably be interested in the bizarre world that came streaming into his earphones via Radio Peking, which, along with Radio Moscow, was one of his favourites in that age of youthful rebellion. During morning recess one day, he told me about the stern hysteria of the Radio Peking announcers. It was 1967; I was thirteen, and the Cultural Revolution was at its height.

Samson invited me home to listen for myself. He encouraged me to write to Peking because, free of charge, they'd send me publications about China. From then on until I left to study in the People's Republic as an exchange student in 1974, I received a flood of printed matter from China: the weekly Peking Review and copies of the monthlies China Reconstructs and China Pictorial. I was attracted to the surreal images of workers and peasants in the magazines, and to 
the Chinese-language corner, but Peking Review, clogging our mailbox (much to the bewilderment of my parents), and printed on impossibly thin dictionary paper, was a challenge: each issue started with long reports on meetings of the Chinese Communist Party, mass rallies in Tiananmen, obscure foreign Communists being feted by Chairman Mao, theoretical screeds on the Cultural Revolution-all of it couched in an English prose that was in turns impenetrable and hilarious. It was my introduction to what, nearly forty years later, I would describe as New China Newspeak 新华文体.

I hardly ever heard Radio Peking myself, unless Samson had me over, but my interest in China, philosophy, politics and history increased. Later, as a student of Chinese in Canberra, I was drilled in correct Peking-inflected pronunciation by our tutor Vieta Dyer, and from second year, 1973, I learned the more dulcet tones of Taiwan-inflected Mandarin. The contrast couldn't have been greater, and when, in 1974, I heard that stern voice admonishing me in the washroom, I had no doubt about the tone, and the demeanour, of Official China.

\section{A measured life}

As students in a late-Cultural Revolution university, our lives were marshalled by the radio. We woke at 6.00 am to the early-morning broadcast calling students to callisthenics. This collective PE routine was the fifth in a series of Cultural Revolution radio callisthenics introduced in 1951. Our broadcast always began with the following words:

Our Great Leader Chairman Mao teaches us: 'Develop physical education, improve the people's strength; raise awareness; defend the motherland!'

伟大领袖毛主席教导我们：发展体育运动，增强人民体质，提高警惕，保卫祖国。

News programs were shouted into the canteens while we ate; morning classes were interrupted by further broadcast callisthenics; lunch was midday news; afternoon broadcasts replaced teatime and the evening meal was ushered in by further news and updates on the daily revolutionary struggle, key quotations from Chairman Mao, the reading out of editorials that would appear in the press the following day, including barely comprehensible theoretical articles on topics like bourgeois rights, capitulationism in the Ming-dynasty novel The Water Margin, as well as denunciations of the Soviet Union. Then there were the mindnumbing reports on the cavalcade of foreign dignitaries met by the revolutionary leadership, or lame student essays from the school PA system that mimicked 
official propaganda. Punctuated with martial music and rousing exhortations, radio broadcasts measured out our days and echoed through our dormitories and classrooms and over the sports fields. When in high school I came top in the year in English, l'd requested as my prize The Selected Poems of T. S. Eliot. In my worldweary adolescence an early favourite was 'The Love Song of J. Alfred Prufrock':

For I have known them all already, known them all:

Have known the evenings, mornings, afternoons,

I have measured out my life with coffee spoons;

I know the voices dying with a dying fall

Beneath the music from a farther room.

So how should I presume?

The verse came to me as clockwork broadcasts punctuated and filled my student life in China.

\section{Diminishing returns}

The fascination with listening to radio broadcasts decreased in proportion to my ability to understand what was being said. At the time, I didn't know it was the end days of what I think of as High Maoism: the two-decade-long ideological stain dating from the Hundred Flowers Movement of 1956, during which people from all walks of life found that they had been lured into 'helping the party improve its work style' and as a result found themselves denounced and, in many cases, sent into internal exile, until the end of both Mao (who died on 9 September 1976) and his class-struggle-based policies, in December 1978.

Our textbooks, novels, comics, the newspapers, the radio, our teachers and our Chinese classmates' conversations reflected that mono-Maoist world. They all found voice in an unforgiving and relentless Sino-logorrhoea, the English version of which I had first heard on Sam's shortwave radio as a thirteen-year-old high school student in Sydney.

Real enemy broadcasts, from the BBC and Radio Australia, became a staple and we listened in enthusiastically, if furtively. As there were no students from the United States (although they would come, trailing their clouds of glory) until after Sino-US normalisation in 1979, the Voice of America was not on our dial. Only later would I learn that VOA, along with Radio Australia, was a staple for Chinese 
radio listeners and enthusiasts (although VOA was jammed until 1976). In fact, Radio Australia, with the proximity of its shortwave transmitters and its mix of light news and lighter music, enjoyed a prominence and cultural status in the 1970 s and 1980 s that is hard to imagine.

In October 1976, only weeks after Mao's death, our class of foreign students was sent on another ritualistic round of 'open-door schooling'. This policy had been introduced during the Revolution in Education that was supposed to bring book- and classroom-bound students into closer contact with lived, productive reality by assigning students to work in people's communes and factories during term time and to learn from the workers-peasants-soldiers (foreign students were barred from assignment to military units).

It was autumn, and our class at Liaoning University was sent to work on an appleproducing commune in Jin County, on the Liaodong Peninsula, not far from Dalian. During the day we worked with the local peasants picking apples; at night we were sequestered in a separate collective dormitory. With little diversion and no entertainment, we often listened to snatches of radio news and music broadcast by Radio Australia. This is how we first heard reports that a group of leaders in the Communist Party Politburo had been detained. It was explosive news, and it was punctuated by military movements around us as army planes flew overhead. We later learned that the air traffic corridor connecting the Shenyang Military Region to Peking was overhead; everyone was alarmed. Meanwhile, the Chinese broadcasts shouted into our dorms, throughout the peasant village and over the fields spoke only in riddles. The main message was gnomic, for it was the oftrepeated mantra calling on the nation to persevere with Three Wants and Three Disavowals 三要三不要:

Want Marxism, Disavow Revisionism;

Want Unity, Disavow Disunity;

Want Openness, Disavow Plots and Intrigue.

要搞马克思主义，不要搞修正主义;

要团结，不要分裂;

要光明正大, 不要搞阴谋论计。

In the capital, party leaders had planned to suppress news of the downfall of a group that would soon be known as the Gang of Four for up to two months while they rounded up their henchmen and women. Professionally trained to be sensitive to every nuance in China's political life, our teachers and cadre-minders 
knew something momentous was afoot. We told them what we had heard on Radio Australia and in recognition of the accuracy of the news they locked us in our dorms, fearful that these enemy broadcasts might foment a local incident. They sent a delegation back to Shenyang to ascertain what was going on. But the news of the arrest had been leaked to the Western media, and Party Central was forced to announce the coup on 14th October.

Those who remained with us in the commune fitfully revealed their disdain for what was now openly denounced as a plot to usurp the party and suborn the revolution in the name of Chairman Mao. Later in the month, by the time we were taken to the port city of Dalian - a reward for an austere stint on the commune, now to participate in a formal celebration of the ousting of the Gang of Fourour local Chinese leaders had accommodated themselves to the latest direction in national life and were doing what can best be described as the 'dialectical backflip' to justify their compliance with, and even enthusiastic imposition of a now discredited political line.

\section{Broadcast letters}

Radio broadcasts ruled the airwaves of China and it was through the radio, more than via any other medium, that the shifting political winds of China's revolution were communicated to the country.

In early June 1966, a letter from Chairman Mao read over the radio announced his support for a group of high school students calling themselves the Red Guards. In mid-August a radio broadcast reported on a mass rally in Tiananmen Square in which the leadership had called for Smashing the Four Olds, leading to a nationwide wave of iconoclasm. It was over the radio that every twist and turn in the Great Proletarian Cultural Revolution was first broadcast.

The voice came from Central Peking Radio, but it was relayed by countless provincial, municipal and local stations, as well as via the small-scale broadcasters in every factory, commune and school. You could be ignorant of the secretive communications of the party, sleep through the imposed political study sessions and avoid reading the daily press, but there was no escape from the incessant, insistent and ubiquitous broadcasts. 
It was the airwaves that would declare the end of the era of Maoist extremism and give notice that a new era was dawning for the People's Republic. Those who spoke more freely and traded rumours in an era of media control and lingering fear were known as 'mini radio stations' 小广播站.

In those years, I encountered, in passing, a recent jailbird: Sidney Rittenberg. It had been nearly ten years since, with Samson Voron, I had listened to the Englishlanguage broadcasts of Radio Peking when I was at high school in Randwick. Rittenberg, a firebrand foreign revolutionary in Maoist Peking, had taken over the radio station where he had previously worked as a foreign expert and where, for a period, he was a Maoist enforcer who brought to the foreign-language service the zealotry that was crowding broadcasts throughout China itself.

He was a small man, steely but grey from nearly a decade in prison. Only some years earlier Chinese Premier Zhou Enlai had declared that Rittenberg was one of the bad people and that 'he will never be allowed freedom'. Sometime in 1978, I spotted him on the Friendship Bus that stopped by the Foreign Languages Press at Baiwan Zhuang, on its afternoon trip to the Friendship Store at Jianguomenwai.

He was still under a cloud, and people spoke of him in hushed tones as Zhou Enlai had supposedly said that for his misdeeds during the Cultural Revolution he must never be allowed a new start 永不得翻身. Only later did I learn that the English-language Radio Peking I had first heard ten years earlier, the voices in the air that l'd heard at Samson Voron's home in Randwick, were from an organisation that had been taken over by Rittenberg as part of the extremist media push by Cultural Revolution radicals. I would also learn that the prose I had come to regard as the formal style of mainland Chinese was further developed around the same time by Chen Boda, one of the most important writers of twentieth-century China, who, along with Mao Zedong's other ideologues, forged a prose style of high dudgeon and extremism that still underpins the tenor of China's official voice in the twenty-first century.

\section{Turn off, tune out}

From 1977 until the early 1990s I often stayed at Baiwan Zhuang. Not long after my time picking apples at the People's Commune in Jin County, I had been introduced to the translators Yang Xianyi and Gladys Yang. They befriended me and invited me to use their apartment as my Beijing home during the years I first worked in Hong Kong and later lived and studied in Japan. Through their 
kindness I learned a little of the workings of China's international propaganda effort in the early post-Cultural Revolution years, and it was because I was living at the Foreign Languages Press, and occasionally took the Friendship Bus into town on shopping expeditions with Gladys, that I bumped into the recently freed Sidney Rittenberg. It was also with Gladys and Xianyi that I enjoyed a rare moment of revenge on the ubiquitous and invasive loudspeakers - so tellingly called laba 喇叭, a word that means both 'loudspeaker' and 'trumpet' in Chinese.

It was the early summer of 1986 and I, along with my soon-to-be-wife Linda Jaivin, and a friend who worked for Libération, Philipe Grangerau, was invited by the Hunan novelist Gu Hua to join Xianyi and Gladys to the film set for the screen adaptation of Gu Hua's popular novel Hibiscus Town, in West Hunan province.

Sitting in our soft-sleeper compartment, I thought that Gladys and Xianyi had probably had enough of incessant broadcasts and mind-numbing lectures from the party. They had both been jailed in the late 1960s for four years: Gladys, a foreign spy, and Xianyi, a corrupting agent of influence. Xianyi was locked up at Banbu Qiao, a prison for common criminals, with a life regimented by broadcasts, study sessions and group discipline. As a high-status agent, Gladys was sequestered at the political prison of Qincheng, on the outskirts of the city, where she was kept in solitary confinement and restricted to hearing news broadcasts and the official press. For Linda the blare was relatively exotic, although annoying; for me it was unbearable: loud, inane and a continuation of the aural force-feeding l'd experienced for over ten years. I climbed on a bunk and 'decommissioned' the loudspeaker. The rest of the trip passed in a happy clamour of our own making.

From early 1978, Chinese TV had produced CCTV News, a thirty-minute nightly program. Feature stories generally mirrored the People's Daily and radio broadcasts, in keeping with the party protocol that maintained a 'unified calibre' 统一口径 in presenting information. During the tumultuous events of the spring-summer of 1989 the evening news was used by the authorities to issue its admonishments, alerts and warnings, as well as its version of what today is known as fake news.

The broadcaster Xing Zhibin had been half of the male-female newsreading team since July 1981. Her voice was famous - as was her matronly appearance, including a helmet-like hairdo. Her clipped and perfectly measured delivery was far from the hysterical style favoured in the Cultural Revolution but was 
nonetheless stern and uncompromising. It was her voice that was heard during the famous 1984 National Day Parade that celebrated Deng Xiaoping's eightieth birthday and again frequently during the dramatic events of 1989. Xing Zhibin's relentless voice seemed as though it could even be heard underwater. Perhaps that's why her work for Zhang Peili remains so compelling.

\section{In a drop of water}

Watching Water: Standard Version from the Cihai Dictionary (1991), featuring the automaton-like Xing Zhibin, I am reminded of a quieter yet more powerful voice, also famous in 1989. It is that of my old friend Yang Xianyi. As the journalist John Gittings noted in the obituary for The Guardian:

In 1987 the party old guard hit back, sacking the reform-minded leader Hu Yaobang, and paving the way for the bloody events around Tiananmen Square two years later. When the crisis came, Yang decided he could no longer shrug politics aside. 'I could at least speak through the foreign TV and newspaper correspondents to the people outside China and tell them the true situation,' he recalled in his autobiography White Tiger (2000).

His message was that what had happened was 'a fascist coup engineered by a few diehards against political reform'. In a BBC interview after the massacre during the night of 3-4 June, Yang declared that the party leaders were even worse than past Chinese warlords or Japanese invaders. The authorities, probably deterred by Yang's age and reputation abroad, left him at liberty, and after a vain attempt to persuade him to recant they merely expelled him from the party.

Xing Zhibin's voice and demeanour resonate still in Zhang Peili's art, work that itself outlives its original place and time. Similarly, Yang Xianyi's voice, although not heard on the airwaves since 4 June 1989, resounds through the timeless translations of Chinese literature that he produced with his wife and partner, Gladys. Both live on, one a silent poetry woven from the Chinese world of letters, the other a poetry created using a discordant voice that reads an artless work.

Note: A version of this essay was first published online for the China Channel of the Los Angeles Review of Books on 4 June 2018, at www.chinachannel.org/2018/06/04/something-in-the-air. A longer version was published by the author at China Heritage, www.chinaheritage.net/journal/something-in-the-air, 8 June 2018. 



\section{空中电波}

\section{白杰明 \\ Geremie R. Barmé}

\section{敌台消息}

“偷听敌台!”

我在北京外国语学院宿舍楼的则所里, 听到一个粗哑的声音如犬吠般从水槽边传来。 我几天前才从澳大利亚来到北京。对方是一个工农兵学员, 在凌晨的黑暗中仍穿着毛 式蓝色立领制服, 面色铁青, 语气中满是警告和指责。他说的话我一个字也没听懂。

“你偷听敌台!”

这是 1974年的十月, 我还是一个天真热切、只在堪培拉学过两年半中文的交换学 生。为了提高中文听力, 我躲在冷得令人生畏的宿舍则所里, 把小收音机放在水槽边 上听广播。我正在收听的频道播音员不像校园喇叭中反复播报的新闻一样顿句强硬, 语速飞快。这个声音几近悦耳, 没有中央人民广播的高六尖利。我想当然的认为, 这 些相对温和的播音大约来自本地甚至外省电台, 他们所讲的中文与我在澳大利亚国立 大学中文课上学习的一样清晰、平稳。

“苏修广播! ”

他依然吼着。“这是苏修广播!”

我的中文老师也教过我们一些基本毛式汉语, 大学三年级时, 我们读过《红旗》杂志 和《人民日报》里的文字, 我在此之前也读过《北京周报》, 可以理解常见词汇, 比 如美帝、苏修、反革命、蒋匪, 还有毛主席说的三座大山, 即封建主义、资本主义、 半殖民主义。作为一个外国人, 我听的自然都是 “敌方电台”，但从未听说 “敌台” 这个听过一次便永生难忘的词汇。我最初接触中央人民广播是在悉尼兰威克男子高中 时期, 我的好友萨姆森 - 沃伦是一个业余无线电爱好者。我们都是星际迷航的死忠 
粉, 萨姆森的俄罗斯血统让他看起来甚至像年轻的史波克, 除了尖耳朵, 他们有一样 平滑的眉眼。萨姆森去不了外太空或异世界, 整夜接收空中电波却也让他成为名副其 实的世界公民。早在那个时候, 他就知道我对道家、藏传佛教和印度神秘主义感兴 趣, 也一定会喜欢从电波中传来的另一个奇异的世界: 北京广播电台。和莫斯科广播 电台一样, 都是他少年反叛时代的最爱。一次晨休时, 他向我提起北京广播电台播音 的锃铭和疯狂。那是 1967 年, 我十三岁, 文化大革命正值高潮。

萨姆森邀请我去他家听广播, 并鼓励我给北京广播电台写信, 因为他们会免费给我 寄有关中国的刊物。从那时起, 直到1974年我作为交换学生来到中国, 我陆续收 到了许多来自中国的报刊杂志, 包括《北京周报》和月刊《中国建设》、《人民 画报》。画报中近乎离奇的农民和工人照片令我着迷, 当然还有讲授中文知识的中 文角。而每周塞满我家邮箱（这让我的父母甚为费解），印在极薄的字典用纸上的 《北京周报》对我而言是一个巨大的挑战：每期刊物都长篇累牍的记述中国共产党 的大小会议、天安门广场群众集会、毛主席宴请不为人知的外国共产主义者、还有 文化大革命的种种理论教条, 内容夹裹在时而费解、时而滑稽的英文里。这成为我 与四十年后被我称作“新华文体”的写作范式的首次接触。

除非萨姆森邀请, 我很少能听到北京广播电台, 但我对中国、哲学、政治和历史的兴 趣与日俱增。后来, 我在堪培拉成为一名中文专业学生, 受到戴老师 (Vieta Dyer) 标准的北京腔调的严格训练。大学第二年, 也就是 1973年, 我又学习了台湾国语柔和 悦耳的发声方式, 二者实在大相径庭。因而, 在 1974年, 宿舍则所里的这个工农兵 学员的严厉责骂, 毫无疑问的向我表明了官方中国声音的调性和姿态。

\section{被度量的生活}

在文化大革命后期, 大学生活完全由广播调遣。我们每天早上六点都要听广播操集合 令起床。集体广播体操首次颁布于 1951 年, 我们做的是第五套广播体操, 也称为文革 体操, 每天都以如下口号开头:

伟大领袖毛主席教导我们：发展体育运动，增强人民体质，提高警惕，保卫祖国。

千篇一律的新闻广播响彻学校食堂; 早课中间还有新一轮广播体操; 午饭时有午间 新闻, 下午茶时间由广播替代, 而晚饭则充斥着每天革命斗争新动向、报告、毛主 席语录、次日见报的社论, 这包括一些晦涩的政论文章, 如资产阶级法权、明代小 说《水汻传》中的投降主义倾向, 还有对苏联的谴责。接下来还有令人头昏脑涨的 革命领袖接见的外国名人名单, 和学校广播里模仿官方宣传的獘脚学生作文。广播 回荡在宿舍、教室和操场上, 中间穿插着军乐和激昂的口号, 我们每日的生活就这 样被它度量。记得高中得年级英语第一名时, 我选择的奖品是《艾略特诗选》, 我厌 世的青少年时期最爱的便是《阿尔弗瑞德・普鲁弗洛克的情歌》： 
因为我已经熟悉了她们，熟悉了她们所有的人-

熟悉了那些黄昏, 和上下午的情景,

我是用咖啡匙子量走了我的生命;

我熟悉每当隔壁响起了音乐

话声就逐渐低微而至停歇。

所以我怎么敢开口?

在中国上学的日子里，每当广播如钟表发条般侵入我的生活，我总会想起这首诗。

\section{收获渐少}

随着我能听懂的广播内容越来越多, 我对广播的着迷程度也随之锐减。在那时, 我并 不知道自己处在毛主义极盛时期的尾声。这个长达二十年的意识形态运动从 1956年 的百花齐放运动开始, 各界人士被诱进 “给党的工作提意见”的 “阳谋” , 遭到批 判, 及多年的自我放逐。直到1976年九月毛泽东去世, 同年十二月以阶级斗争为纲 的政策才得以结束。

不论是教材、小说、连环画、报纸、广播、还是同学和老师们的谈话, 都是毛时代单 一价值社会的体现, 他们口里的中文如出一辙, 都是同样的无情、飞快、而且喋喋不 休。我十三岁在悉尼上高中时第一次在萨姆的短频收音机里听到就是这种说话方式的 英文版本。

货真价实的敌台，比如澳洲广播电台和英国广播公司BBC，是我们秘密文化生活的支 柱。那时的留学生同学中没有美国人一一当然, 1979年中美关系正常化之后, 美国 学生们也驾着祥云荣耀而至一一美国之音因此不在我们的收听范围。后来我才知道, 美国之音和澳洲广播都是中国广播爱好者的最爱, 虽然美国之音在 1976年前都受到 信号干扰。澳广由于短波发射台地理位置靠近中国, 新闻消息和音乐皆轻松入耳, 在 七八十年代的中国曾拥有今天难以想象的文化地位。

1976年十月, 毛泽东去世后的短短几周内, 我们一班外国学生被送往新一轮“开门 办学”。这个政策出自文革后期的教育革命, 要求死啃书本的学生走出教室, 投入真 实的生产生活, 在学期中到公社和工厂劳动, 向工农兵学习一一当然, 我们这些外国 人是不允许分配到军事单位的。

那个秋天, 我和一班同学从辽宁大学被分配到辽东半岛, 在大连附近金县的一个苹果 生产大队劳动。白天, 我们和当地农民一起采摘苹果, 晚上住在隔开的集体宿舍里。

由于生活单调, 缺乏娱乐, 我们经常私下零碎地收听澳洲广播电台的新闻和音乐节 目, 也是由此才得知中央政治局里有政治集团被捕的消息。这个极具爆炸性的新 
闻, 加上周边的军事行动、空中飞过的战机, 都使我们意识到事态严峻。后来我们 发现, 沈阳军区到北京军区的空中走廊就在我们头顶, 大家都感到十分紧张。与此 同时, 回响在宿舍、村庄和田地里的中文广播依然日复一日的播送着语焉不详的警 示, 重复最多的便是 “三要三不要” :

要搞马克思主义，不要搞修正主义;

要团结，不要分裂;

要光明正大, 不要搞阴谋论计。

在四人帮及其支持者被拘捕期间，“粉碎四人帮” 的消息被北京领导层严格封锁长达 两个月之久。而我们的老师和干部多年来练就了高度的政治敏感, 已经意识到有剧变 正在发生。我们说出了在广播中听到的消息, 他们意识到情况属实, 就把我们关在宿 舍里, 生怕敌台信息的散播会造成地方混乱, 还派人去沈阳确认消息的真实性。事实 上, 四人帮被捕的消息已经外泄给西方媒体，党中央也已于十月十四日公开此次政变。

对四人帮篡党夺权、以毛主席之名破坏革命的大批判开始后, 和我们一起留在公社的 人也会偶尔表达出鄙视之情。十月底, 我们被送去大连参加“粉碎四人帮” 的官方庆 祝活动, 作为在公社艰苦生活的奖赏。这些地方干部已经迅速适应了国家的新方向, 在他们曾经服从甚至积极拥护的政治路线倒台之后, 立即进行了一场高难度的意识形 态大转弯。

\section{广播作为文体}

看不见的电波主宰着中国领空，也先于其它媒介，成为中国革命政治风向和动荡的主 要传声筒。

1966年六月初, 毛泽东通过广播宣布支持一队自称 “红卫兵” 的高中学生。八月中 旬, 在天安门广场的群众集会上, “破四旧” 的上层号召通过广播传往各地, 掀起了 全国范围内大肆破坏传统的风潮。文化大革命期间, 大大小小的政治变动和转向同样 依靠广播下达。

这些播报出自北京广播电台, 传达到每个省市县份的地方电台, 再下达到所有工 厂、公社、学校的自有广播站。你可以忽略党的语焉不详的通讯, 可以在政治学习课 上睡大觉，也可以不读书看报，但无处不在、永无休止的广播却着实让人无所遁藏。

同样通过空中电波，人们得知了毛式极权统治的结束，以及中华人民共和国新时代的 到来。在那个严格管控媒体、人人心有余悸的时代, 人们把能说会道、爱传小道消息 的人叫做 “小广播站”。 
那些年中, 我短暂结识了刚出狱的李敦白 (Sidney Rittenberg)。这距离我初次和萨 姆森・沃伦一起收听北京广播电台刚好过去了十年。在毛主义控制下的北京, 李敦白 这位激进的外国革命者掌控了他曾担任外国专家的北京广播电台, 将这场席卷中国听 众的革命狂热带入外文播报中。

李敦白个子不高, 外表刚毅, 近十年的牢狱生涯却使他满头灰白。此前不久, 周恩 来总理才批示过, 李敦白是坏份子, “决不能让他自由。” 1978年的某个下午, 我 看到他坐在一辆前往建国门外友谊商店的友谊巴士上, 在百万庄大街外文出版社门 前停靠。

那时李敦白仍然生活在政治阴影下，因为周恩来说他在文革中做了坏事，永不得翻 身, 人们只敢小声谈论他。后来我才发现, 我十年前在悉尼萨姆森家听到的北京广 播, 正是在李敦白的控制下, 投入文革狂热份子掀起的激进宣传浪潮。我也了解到, 被我视作中国大陆官方文体的写作范式，大多出自陈伯达的手笔，作为二十世纪中国 最重要的文胆之一，他与其他毛泽东御用文人共同创造了一种集激愤与极端论调于一 身的写作风格, 并仍然决定着二十一世纪中国官方言论的基调。

\section{关机换台}

从1977年到1990年代初, 我时常住在百万庄。离开金县的摘苹果的人民公社后不 久, 我被介绍给翻译家杨宪益和戴乃迭 (Gladys Yang) 夫妇。我们成为了朋友。我开 始在香港工作, 以及后来去日本求学居住期间, 他们的公寓成为了我在北京的家。在 他们的介绍下, 我开始了解文革结束初期中国面向国际的宣传手段。由于我住在外文 局, 有时会乘坐友谊巴士和戴乃迭一起去友谊商店购物, 我才能遇到出狱不久的李敦 白。也是与二老在一起时, 我得到了一个难得的机会, 对无所不在、无孔不入的播音 喇叭实施一次小小的报复——“喇叭”这个词在中文里同时代表小号和扩音器。

那是 1986年的初夏, 我和即将成为我妻子的贾佩琳, 我的朋友、法国《解放报》记 者菲力浦 · 格朗日罗 (Philippe Grangereau) 受湖南小说家古华邀请, 与杨宪益和戴 乃迭一道去湘西参观他广受欢迎的小说《芙蓉镇》改编电影的拍摄现场。

坐在软卧车厢里, 我心想, 对各种无休止的播报和令人麻木的讲话, 杨宪益和戴乃迭 一定不堪其扰。他们二人曾在六十年代末㥿过四年的牢狱生涯, 戴乃迭被指控为外国 间谍, 杨宪益的罪名则是反动权威。杨宪益被关在半步桥监狱, 狱友多是普通囚犯, 日常活动包括听广播、参加学习班和集体管教。戴乃迭的身份是高级特工, 被单独监 禁在专门关押政治犯的京郊秦城监狱, 每日只能听到新闻播报和官方宣传。贾佩琳觉 得广播虽然扰人却尚颇为新奇, 而我实在忍无可忍：这种一如既往的高亢、空洞, 十余年来末曾改变的强制听觉折磨, 促使我爬到上铺, 关掉了喇叭。余下的旅途 中, 车厢里只剩我们愉快的喧闹声。 
1978年一月, 中央电视台启播每日晚间时长三十分钟的《新闻联播》, 在统一口径 的指示下，其信息播报与《人民日报》和各大广播电台保持一致。在 1989年春夏之 交的风波中, 《新闻联播》亦成为当局喉舌, 发布指示、通知、警告、以及今天被 我们称为 “假新闻” 的虚假消息。邢质斌自 1981 年七月起担任新闻联播男女主播搭 档之一, 她的声线, 女舍监般的庄重外表, 以及头盔似的标志性短发在中国家喻户 晓。邢质斌的播音清晰严谨, 与文革时期的锃铭激昂截然不同, 却仍显得强硬和刻 板。她解说了 1984年为邓小平八十周岁庆生的国庆阅兵, 也大量参与了六四事件的 报道。她的音色如此冷峻, 仿佛在水下也能传播一一这也是邢质斌在张培力作品中 的朗读时至今日仍然震撼人心的原因。

\section{滴水见世界}

观看《水一一辞海标准版》中邢质斌机械的朗读, 我想起了另一个更加沉静却更为有 力的声音, 一个在同样在 1989 年出名的声音, 这便是我的老友杨宪益。约翰 - 基廷 斯 (John Gittings) 为英国《卫报》撰写的认告中这样写道:

1987年, 共产党的守旧势力重新占据上风, 胡耀邦因改革而下台, 并为两年后血腥的 北京事件埋下伏笔。当危机来临, 杨宪益决定不能再对政治表现出事不关已的姿态。 他在2000年的自传《白虎》（White Tiger）中写道：“我至少能通过国外电台和报 社记者向国外的人对话, 让他们了解真实情况。”

杨宪益将所发生的一切描述为“少数保守顽固分子针对政治改革所进行的一次法西斯 政变。”他在学潮发生后接受BBC的一次采访中声称, 党的领导人比过去的中国军阀 和日本侵略者更加恶劣。当局或许考虑到了杨宪益的年龄以及他在国外的名声, 没有 剥夺他的自由之身, 在试图劝说他收回言论无果之后, 他们只是将他开除党籍而已。

邢质斌的朗读和举止在张培力的作品中得以脱离原本的时空存在。同样的, 杨宪益的 声音尽管在1989年六月四日后再无公开播放, 却依然留存在杨戴二位先生的不朽译 作中。这两种声音都将继续存在, 无论是由汉语文学经典编织出的沉默的吟咏, 还是 声音和无味之辞的失谐组合产生的诗歌。

注: 本文的一个版本于2018年6月4日首次在线发布于《洛杉矶书评》中华频道, 网址为 www.chinachannel. org/2018/06/04/something-in-the-air。此文更长的版本于2018年6月8日发表在《遗典》（China Heritage）上, 网址为 www.chinaheritage.net/journal/something-in-the-air。 
This text is taken from Zhang Peili: From Painting to Video, edited by Olivier Krischer, published 2019 by ANU Press, The Australian National University, Canberra, Australia.

doi.org/10.22459/ZP.2019.03 